\title{
The Influence of Genetic Factors on the Productivity of Holstein Cows
}

\author{
Belenkaya Anzhelika Yevgenievna \\ Department of feeding and breeding farm animals \\ Federal State Budgetary Educational \\ Institution of Higher Education \\ «Northern Trans-Ural State Agricultural University» \\ Tyumen, Russia \\ belenkayaae@gausz.ru
}

\author{
Tatarkina Nina Ilyinichna \\ Department of technology of production and \\ processing of livestock products \\ Federal State Budgetary Educational \\ Institution of Higher Education \\ «Northern Trans-Ural State Agricultural University» \\ Tyumen, Russia \\ tatarkinani@gausz.ru
}

\begin{abstract}
The article presents the data on productive and reproductive qualities of cows of Holstein breed depending on genetic factors. The cows of the line by $R$. Sovering were characterized by higher productive qualities during their first and third lactation. Cows of all three lines are characterized by the optimal duration of interaction period and longer service period, which lead to an increase in the calving interval. In the process of studying the effect of different methods of selection on milk productivity of Holstein breed cattle, the authors found that during intra-line selection higher productivity is characteristic of the selection by R. Sovering and V.B. Ideal. The period of production use of the analyzed livestock amounts to 2.8 lactations. Cows from the M. Chieftain line are characterized by 3.0 lactation. At the same time the eliminated cows of the line $R$. Sovering were characterized by higher productivity, the yield for lactation made $8462.8 \mathrm{~kg}$.
\end{abstract}

Keywords - Holstein cattle, line, selection, yield, correlation, productive longevity.

\section{I.INTRODUCTION}

Intensification of dairy cattle breeding of Russia greatly enhances the interbreed competition, leading to expansion of cultivation and increasing population of animals of the most competitive breeds. As you know, Holstein cattle animals have a high milk yield and good technological qualities in comparison with other breeds possessing dairy productivity $[1,2]$.

The Holstein breed is the most productive in the world, is a specialized dairy type with a great live mass, selected for its suitability to industrial technology and is an outstanding achievement in genetics and selection $[3,4,5]$.

In the Tyumen region the share of Holstein breed, which is represented mainly by Dutch and German selection, accounts for $29 \%$ of the total number of dairy cattle $[6,7]$.

The Holstein breed is of the milk type, obtained by selection of the minimum number of traits, mainly for the yield of milk accounting for the milk fat output and body type. Holstenisation is one of the main ways to increase milk productivity of dairy breeds, bred in the country [8].
In modern breeding the main importance is given to the problem of estimation of pedigree qualities of animals. The quality of future generations, hence the progress in the population, breed or herd, depends on its objectivity and accuracy. Given that the method of artificial insemination allows obtaining a significant number of descendants from one supplier, a paramount role in the programs of genetic improvement of populations of dairy herds is given exactly to the accuracy of prediction of the breeding value of bulls [9]

Milk yield is the main indicator of dairy cattle. It is known that the indices of milk productivity (milk yield, fat and protein in milk) due to the genotype of the animal and the environmental conditions which it is implemented in [10].

The variability of the main characteristics of milk production is characterized by the following indicators: yield $20-30 \%$, the fat content in milk - 4-10\%, protein - 3-9\%. A smaller variability in fat and protein milk is due to their higher genetic determination and the heredity conservatism of these traits. So, the coefficients of inheritance (the share of genetic variability transmitted from parents to descendants) are equal to $10-30 \%$ for the yield of milk, for fat content of milk - 50-80\%, for protein milk - 40-70\%, for living mass - 30-50\%. These differences are caused both by heredity and the influence of external conditions, the intensity of selection, type selection, the genealogical structure of the herd and other causes.

International practice, especially in countries with developed dairy cattle breeding, shows that the main elements in the breeding business are the identification and recruitment of parental pairs with outstanding productivity for a customized pairing, receiving and bringing up their offspring, early comprehensive assessment of servicing bulls, identifying improvers and the use of their tribal enterprises for artificial insemination [11].

The use of highly productive animals of imported selections allows in short terms to increase the level of milk production and profitability. However, the introduction of animals to new conditions often leads to a reduction in economically useful and, first and foremost, productive traits 
Genetic improvement is largely due to the intense and targeted selection of highly productive animals [12].

The system of selection allows essential changing the basic constants characterizing the genetic status of a population, and, consequently, influencing the efficiency of further selection. The acceleration of genetic progress is achieved through the use of the intralinear rebounds and cross lines [13].

The main driving forces of selection are the selection of animals and selection of pairs. If the purposeful selection allows getting rid of animals that do not meet the objectives of breeding, the selection provides an opportunity to design new organisms characterized by higher characteristics due to the desired breeding grounds. This defines the creative function of selection. Although practice and science have identified a number of rules of tribal selection, it is still a complex creative process $[14,15]$.

\section{A. The main goal}

The aim was to study the influence of genetic factors on the productivity of Holstein cows.

\section{II.METHODS AND TECHNIQUES OF RESEARCH}

The research was conducted at the breeding plant of PJSC "PF Borovskaya" on breeding full-blood Holstein cattle.

The object of the study was the cows of Holstein breed, servicing bull lines: Vis Back Ideal 1013415 (V. B. Ideal), Montvic Chieftain 95679 (M. Chieftain), Reflection Sovering 198998 (R. Sovering).

The analysis was applied to the data of production and breeding records: magazines of control milking, weighing animals, artificial insemination, cards of cows 2-MOL, catalogues of servicing bulls.

Productive qualities of cows of Holstein breed have been estimated depending on a linear accessory and a method of selection.

During the scientific-economic experience, animals were in identical conditions of feeding and maintenance. Feeding is carried out according to the diets accepted in the household, tailored to the period of lactation, milk yield, live weight and physiological state.

\section{III.THE RESULTS OF THE STUDY}

Living Mass is the most important indicator of animal development in different age periods. It is important to consider the weight of herd replacements because in the future it is possible to predict cow productivity.

Dynamics of changes in live weight of heifers depending on the linear facilities are presented in table 1.

At birth, the living mass of heifers of line by M. Chieftain made $34.2 \mathrm{~kg}$, that is $0.9 \mathrm{~kg}$ less than of heifers of line by V.B. Ideal and R. Sovering.
TABLE 1 DyNAMiCS OF LIVE WEIGHT CHANGES, KG

\begin{tabular}{|c|c|c|c|}
\hline \multirow{2}{*}{ Indicator } & \multicolumn{3}{|c|}{ Line } \\
\cline { 2 - 4 } & $\begin{array}{c}\text { V. B. Ideal } \\
(n=97)\end{array}$ & $\begin{array}{c}\text { M. Chieftain } \\
(n=59)\end{array}$ & $\begin{array}{c}R . \text { Sovering }(n= \\
161)\end{array}$ \\
\cline { 2 - 4 } & $\overline{\mathrm{X}} \pm \mathrm{S} \overline{\mathrm{x}}$ & $\overline{\mathrm{X}} \pm \mathrm{S} \overline{\mathrm{x}}$ & $\overline{\mathrm{X}} \pm \mathrm{S} \overline{\mathrm{x}}$ \\
\hline $\begin{array}{c}\text { Live weight: } \\
\text { at birth }\end{array}$ & $35.1 \pm 0.26$ & $34.2 \pm 0.34^{*}$ & $35.1 \pm 0.22$ \\
\hline 6 months & $168.0 \pm 1.14$ & $168.6 \pm 1.43$ & $168.9 \pm 1.17$ \\
\hline 10 months & $272.8 \pm 1.73$ & $280.8 \pm 2.38^{* *}$ & $272.9 \pm 1.76$ \\
\hline 12 months & $325.4 \pm 1.94$ & $330.7 \pm 2.21$ & $326.3 \pm 2.00$ \\
\hline
\end{tabular}

At the age of 6 months, the live weight of heifers of all three lines is almost identical and averages $168.6 \mathrm{~kg}$. At the age of 10 months, the living mass of heifers of line by M. Chieftain made $280.8 \mathrm{~kg}$, that is $7.9 \mathrm{~kg}$ more than of heifers of line by V.B. Ideal. At the age of 12 months, the living mass of heifers of line by V.B. Ideal made $325.4 \mathrm{~kg}$, that is $5.3 \mathrm{~kg}$ less than of heifers of line by M. Chieftain.

According to the requirements of the standard, the heifers of the Holstein breed at 10 months should have a live weight of $260 \mathrm{~kg}$ [16]. So, the heifers of lines by V.B. Ideal and R. Sovering at 10 months exceeded the standard by $5 \%$ for live weight, the heifers of the line by M. Chieftain - by $7.6 \%$. At 12 months the living mass of heifers, according to the standard, should be $300 \mathrm{~kg}$. The heifers of lines by V.B. Ideal exceed the standard by $8.5 \%$ for live weight, the heifers of the line by $\mathrm{M}$. Chieftain - by $10.2 \%$, the heifers of the line by R. Sovering - by $8.8 \%$.

In dairy cattle, breeders constantly address the difficult task - to create a dairy herd with the best combination of milk yield and fat content in milk among cows.

Breeding lines mean creating a highly productive and genetically stable groups of animals on the basis of using a particular system of selection of the outstanding producer and its most valuable offspring obtained in a number of generations in the conditions conducive to the development of particular characteristics and properties of animals which are valuable for the given lines $[17,18,19]$.

The productivity of cows of different lines is represented in table 2 .

TABLE 2 PRODUCTIVITY OF COWS OF DIFFERENT LINES

\begin{tabular}{|c|c|c|c|}
\hline \multirow{2}{*}{ Indicator } & \multicolumn{3}{|c|}{ Line } \\
\cline { 2 - 4 } & $\begin{array}{c}V . \text { B. Ideal } \\
(n=97)\end{array}$ & $\begin{array}{c}\text { M. Chieftain } \\
(n=59)\end{array}$ & $\begin{array}{c}R . \text { Sovering } \\
(n=161)\end{array}$ \\
\cline { 2 - 4 } & $\overline{\mathrm{X}} \pm \mathrm{S} \overline{\mathrm{x}}$ & $\overline{\mathrm{X}} \pm \mathrm{S} \overline{\mathrm{x}}$ & $\overline{\mathrm{X}} \pm \mathrm{S} \overline{\mathrm{x}}$ \\
\hline $\begin{array}{c}\text { Milk yield for 305 } \\
\text { days of lactation, } \mathrm{kg}\end{array}$ & $7846.2 \pm 75.50$ & $7529.9 \pm 100.07^{*}$ & $7998.8 \pm 54.7$ \\
\hline $\begin{array}{c}\text { Mass Share } \\
\text { of Fat,\% }\end{array}$ & $4.2 \pm 0.04$ & $4.2 \pm 0.04$ & $4.4 \pm 0.05^{* * *}$ \\
\hline $\begin{array}{c}\text { Mass Share } \\
\text { of Protein, } \%\end{array}$ & $3.2 \pm 0.01$ & $3.2 \pm 0.01$ & $3.1 \pm 0.01^{*}$ \\
\hline Milk fat, $\mathrm{kg}$ & $329.5 \pm 3.79$ & $316.3 \pm 4.51^{*}$ & $351.9 \pm 4.21^{* * *}$ \\
\hline Milk protein, $\mathrm{kg}$ & $251.1 \pm 2.42$ & $241.0 \pm 3.17^{*}$ & $248.0 \pm 1.80$ \\
\hline
\end{tabular}


Maximum milk yield for 305 days of lactation among heifer cows of the line by R. Sovering made $7998.8 \mathrm{~kg}$, which is $2 \%$ more than at the cow line by V.B. Ideal and $6 \%$ more than at the cow line by M. Chieftain. Mass share of protein is same and constitutes $3.1-3.2 \%$ in the milk of cows from all lines.

The mass share of fat constitutes $4.4 \%$ in the milk of cowheifers of all lines. Milk fat from the cow line by R. Sovering was obtained significantly more by $6.8 \%(\mathrm{P}=0.999)$.

The cows of the line by R. Sovering gave significantly more milk fat of $351,9 \mathrm{~kg}$, which is $10 \%$ more than from cows of lines by M. Chieftain. The cows of the line by M. Chieftain gave 241 $\mathrm{kg}$ of milk protein. The cows of the line by V.B. Ideal gave 10 $\mathrm{kg}$ more milk protein and the cows of the line by R. Sovering gave $7 \mathrm{~kg}$ more in comparison with M. Chieftain's cows.

Analyzing the data on production of cows in the 2nd lactation, we can conclude that the V. B. Ideal's cows have the yield amounted to $9092.8 \mathrm{~kg}$, which is $557.4 \mathrm{~kg}$ more than of the M. Chieftain's cows and $600.8 \mathrm{~kg}$ more than of the R. Sovering's cows $(\mathrm{P}=0.95)$. The mass share of protein constitutes $3.1-3.2 \%$ in the milk of cows from all lines. Milk fat from the cow line by R. Sovering was received $267.9 \mathrm{~kg}$ ( $\mathrm{P}>0.95)$.

The yield from R. Sovering's cows made $9028.5 \mathrm{~kg}$ for the 3rd lactation. The milk yield from M. Chieftain's cows was $374.2 \mathrm{~kg}$ less than from R. Sovering's cows. The mass share of fat constitutes $5.0 \%$ in the milk of M. Chieftain's cows $(\mathrm{P}>0.95)$. The V.B. Ideal's and M. Chieftain's lines show a mass share of protein equal to $3.2 \%$ in milk.

Dynamics of reproductive qualities of cows depending on the linear relationship to the 1st lactation are presented in table 3.

TABLE 3 Reproductive QUALITIES OF COWS

\begin{tabular}{|c|c|c|c|}
\hline \multirow{2}{*}{ Indicator } & \multicolumn{3}{|c|}{ Line } \\
\cline { 2 - 4 } & $\begin{array}{c}\text { V. B. Ideal } \\
(n=97)\end{array}$ & $\begin{array}{c}\text { M. Chieftain } \\
(n=59)\end{array}$ & $\begin{array}{c}\text { R. Sovering } \\
(n=161)\end{array}$ \\
\cline { 2 - 4 } & $\overline{\mathrm{X}} \pm \mathrm{S} \overline{\mathrm{x}}$ & $\overline{\mathrm{X}} \pm \mathrm{S} \overline{\mathrm{x}}$ & $\overline{\mathrm{X}} \pm \mathrm{S} \overline{\mathrm{x}}$ \\
\hline $\begin{array}{c}\text { Service-period, } \\
\text { days }\end{array}$ & $119.7 \pm 5.89$ & $140.1 \pm 9.47$ & $134.4 \pm 5.57$ \\
\hline $\begin{array}{c}\text { Interlactation } \\
\text { period, days }\end{array}$ & $58.8 \pm 1.0$ & $61.8 \pm 1.55$ & $59.7 \pm 1.04$ \\
\hline $\begin{array}{c}\text { Calving interval, } \\
\text { days }\end{array}$ & $399.7 \pm 5.89$ & $420.1 \pm 9.47$ & $414.4 \pm 5.57$ \\
\hline
\end{tabular}

The duration of the service-period among cows for the first lactation is quite high. A more optimal duration of service period was identified among V.B. Ideal's cows - up to 119.7 days. The duration of the calving interval for the first lactation among V.B. Ideal's cows was 399.7 days, which is $3.6 \%$ and $4.7 \%$ less than among cows of the R. Sovering's and M. Chieftain's lines respectively.

The interlactation period among V.B. Ideal's and R. Sovering's cows for the 2nd lactation lasted for 58.6 and 57.5 days respectively $(\mathrm{P}>0.95)$.

The cows of the line by M. Chieftain had an interlactation period of 63.5 days. The duration of the service period among
M. Chieftain's cows was 167.7 days, which is 18.3 and 23.3 days or $12.2 \%$ and $16.1 \%$ more than among the cows of the R. Sovering's and V.B. Ideal's lines respectively.

The duration of the service period among R. Sovering's cows for the 3rd lactation was 120.6 days, which is $9.1 \%$ and $17 \%$ less than among the cows of the M. Chieftain's and V.B. Ideal's lines respectively.

All economic-useful traits are genetically linked to one degree or another and have complex interdependencies. The most significant in breeding dairy cattle are the correlation coefficients between indicators of milk production and reproductive performance.

So, the revealed negative correlation between the milk yield for 305 days of lactation and a mass share of fat from cows of V.B. Ideal's and M. Chieftain's lines $r=-0,26(P>0.99)$. A weak positive correlation between the mass share of fat and protein is observed in the line by M. Chieftain $r=0.32(\mathrm{P}>0.95)$. Correlation relationship is reliable between the service-period and yields for 305 days of lactation and between the serviceperiod and milk fat was 0.38 and 0.39 among the V.B. Ideal's cows respectively $(\mathrm{P}>0,999)$. The $\mathrm{M}$. Chieftain's cows had the correlation between the milk yield and live weight at the first fruitful insemination which made up $0.30(\mathrm{P}>0,95)$.

The progress of any herd depends on the degree to which the offspring inherit the productive qualities of cow breeding core. According to the productivity of cows the coefficients of heritability were calculated on the basis of the doubled correlation coefficient between the indices of productivity of mothers and daughters, the data are presented in table 4 .

TABLE 4 COEFFICIENTS OF HERITABILITY

\begin{tabular}{|c|c|c|c|}
\hline \multirow{2}{*}{ Indicator } & \multicolumn{3}{|c|}{ Line } \\
\cline { 2 - 4 } & V. B. Ideal & M. Chieftain & R. Sovering \\
\hline Milk yield, kg & $0.35^{* *}$ & $0.43^{* *}$ & $0.40^{* * *}$ \\
\hline $\begin{array}{c}\text { Mass } \\
\text { proportion of } \\
\text { fat,\% }\end{array}$ & $0.35^{* *}$ & $0.34^{*}$ & 0.01 \\
\hline $\begin{array}{c}\text { Mass share of } \\
\text { protein,\% }\end{array}$ & 0.03 & 0.17 & 0.02 \\
\hline
\end{tabular}

Analyzing these tables, we can conclude that the daughters of the V.B. Ideal's line inherit to the equal degree both the milk yield and fat share, mass share of protein is inherited to a lesser degree. The line by M. Chieftain inherits to a large extent the yield coefficient $-0.43(\mathrm{P}>0.99)$. The daughters of the line by R. Sovering inherit only the yield.

In selection and breeding work, the selection is of fundamental importance as it completes the work on the identification of breeding value and selection of the best animals for their further use. It is based on preserving and strengthening qualitative economic-useful features which are being selected [20].

Along with the intra-line selection, one of the important ways to further increase the productivity of animals should consider interline crosses [17]. 
However, not all lines are well combined with each other at crosses. Sometimes a small breed or a line witness the attenuation of selection progress at long-term use of moderate inbreeding. Then the "refreshment of blood" is applied, a technique long been known in animal husbandry. "Refreshment of blood" is carried out through the use of breeding males and females of inbreeding and other factory types as well as breeding males of the same breed of foreign selection [21].

At intra-line selection, the R. Sovering's milk yield for 305 days of lactation totalled $8111 \mathrm{~kg}$ which is $3 \%$ higher than that of V.B. Ideal's and 7\% than M. Chieftain's. The cows of the line by R. Sovering and V.B. Ideal gave a mass share of fat of $4.3 \%$, which is $0.1 \%$ more than from cows of lines by $\mathrm{M}$. Chieftain. The mass share of protein constitutes $3.1-3.2 \%$ in intra-line selection.

Milk yield for 305 days of lactation in the cross-lines by M. Chieftain $\times$ R. Sovering made $7959 \mathrm{~kg}$, in reverse crossing R. Sovering $\times$ M. Chieftain made $4 \% \mathrm{~kg}$ less. In the cross $\mathrm{M}$. Chieftain $\times$ V.B. Ideal the cows gave $7849.2 \mathrm{~kg}$ of milk, in the cross V.B. Ideal $\times$ M. Chieftain $-8.5 \%$ less. The content of fat in the milk of cows, obtained from the cross-line $\mathrm{M}$. Chieftain $\times$ R. Sovering was $4.7 \%$, which is $0.6 \%$ less than in the reverse crossing $\mathrm{R}$. Sovering $\times \mathrm{M}$. Chieftain. The mass share of protein constitutes $3.1-3.2 \%$ in different cross-lines.

In comparison with the mothers, daughters were characterized by lower productivity. So, at the intra-line selection by R. Sovering, the productivity of mothers was 750 $\mathrm{kg}$ of milk more than that of the daughters $(\mathrm{P}>0.999)$. In the cross-line R. Sovering $\times$ V.B. Ideal, the productivity of daughters was $278 \mathrm{~kg}$ of milk more than that of the mothers.

In the analysis of the selection methods, we can conclude that the most effective use of the intra-line selection by $\mathrm{R}$. Sovering and V.B. Ideal. Milk yield of these groups in terms of baseline figures was $9246.4 \mathrm{~kg}$ and $8983.5 \mathrm{~kg}$ respectively. It is possible to obtain additional products of 11.2 and 7.3 thous. RUB in monetary terms per head respectively. Among crosses, the most successful combinations were in the lines M. Chieftain $\times$ R. Sovering and M. Chieftain $\times$ V. B. Ideal, the yield of milk from the cows for 305 days of lactation were 9471.7 and 9026.6 $\mathrm{kg}$ respectively in terms of basic indicators, and the additional product was received in terms of value of 18.3 and 12.2 thous. RUB per head respectively.

At a comparative characteristic of lines and methods of selection, it is recommended for further breeding to use the lines by M. Chieftain and R. Sovering. In the selection of lines the previously used manufacturers were taken into account. So the line by V.B. Ideal was represented by the branch K. Manfred, you can pay attention to the branches Prelude, Besne Beech. The line by M. Chieftain is represented in the given economy by branches K. Belman and Elton, we propose to use the representatives of the E. B. Elton.

The line R. Sovering previously used the branch, H. Ambrose, it is desirable to use the branch Royalty, C. Patron at the intra-linear selection.

The duration of the productive use of dairy cattle is not only a biological but also an economic indicator, as the effectiveness of managing the branch of dairy cattle breeding is largely dependent on the timing of industrial use of cows. Short-term use causes economic damage [22]. Effective means of doing this is to increase the terms of using cows.

Long-term use of highly productive cows contributes to obtaining valuable offspring, improving the genealogical structure of the herd or breed and accumulating genetic potential in subsequent generations [23].

Continued use of cows gives you the opportunity to conduct the breeding work at a higher level. Firstly, prolonged use of highly productive animals has a positive impact on improving the quality of herds, the increase of its productivity by increasing the selective differential. Secondly, long-used topperforming cows in the herd are a good criterion of constitution strength and resistance to disease. Thirdly, it becomes possible to assess the animal not only by productivity, conformation, origin but also by the offspring [24].

The lengthening of the term of productive use is an important and urgent problem of modern cattle breeding [25].

According to our research, it was found that the productivity and duration of economic use are interrelated.

692 heads were culled for five years. Of the total number of retired cows there were $25.4 \%$ of the animals eliminated after the 1 st lactation, $23.4 \%$ after the 2 nd one, $21.0 \%$ after the $3 \mathrm{rd}$ one, and $30.1 \%$ - after the 4 th and later ones. The average lifetime milk production of retired cows for the first lactation is $7841.6 \mathrm{~kg}$, fat content $-4.3 \%$, mass share of protein is $3.2 \%$.

Lifetime productivity of the analyzed retired population is $8619.2 \mathrm{~kg}$ of milk, fat content $-4.5 \%$, mass share of protein $3.2 \%$.

The productivity of cows and the period of practical use, depending on the lineage, are given in table 5.

TABle 5 - Productivity AND THE TERM OF ECONOMic USE DEPENDING ON THE LINEAGE $\overline{\mathrm{X}} \pm \mathrm{S} \overline{\mathrm{X}}$

\begin{tabular}{|c|c|c|c|c|c|c|}
\hline \multirow{2}{*}{ Line } & \multirow{2}{*}{$\begin{array}{c}\text { Period of use } \\
\text { (lactation) }\end{array}$} & $\begin{array}{c}\text { Ailk yield per lactation, } \\
\mathrm{kg}\end{array}$ & $\begin{array}{c}\text { Mass proportion } \\
\text { offat, } \%\end{array}$ & Milk fat, $\mathrm{kg}$ & $\begin{array}{c}\text { Mass share of } \\
\text { protein, } \%\end{array}$ & Milk protein, $\mathrm{kg}$ \\
\hline V. B. Ideal & $2.7 \pm 0.11$ & $8460.9 \pm 79.49$ & $4.3 \pm 0.03$ & $366.7 \pm 4.49$ & $3.2 \pm 0.01$ & $269.2 \pm 2.56$ \\
\hline M. Chieftain & $3.0 \pm 0.11$ & $8432.3 \pm 82.05$ & $4.4 \pm 0.04$ & $375.0 \pm 4.90$ & $3.2 \pm 0.01$ & $267.5 \pm 0.09$ \\
\hline R. Sovering & $2.6 \pm 0.10$ & $8462.8 \pm 75.02$ & $4.4 \pm 0.03$ & $370.4 \pm 4.14$ & $3.2 \pm 0.01$ & $267.7 \pm 2.45$ \\
\hline Total & $2.8 \pm 0.11$ & $8452.0 \pm 78.85$ & $4.4 \pm 0.03$ & $370,7 \pm 4,51$ & $3.2 \pm 0.01$ & $268.1 \pm 2.54$ \\
\hline
\end{tabular}


The table data show that the period of economic use of the analyzed cow population is equal to 2.8 lactations. Cows of $\mathrm{M}$. Chieftain's line kept the herd for 3.0 lactations, of V.B. Ideal's line -2.7 lactations and of R. Sovering's line - 2.6 lactations.

The retired cows of the line by $\mathrm{R}$. Sovering were characterized by higher productive qualities, as milk yield during the lactation period amounted to $8462.8 \mathrm{~kg}$, which is 30 $\mathrm{kg}$ more than from M. Chieftain's cows. Cows all lines had almost the same fat and protein content in milk.

The main reasons for cow retirement in all lines are diseases of the digestive system (27-32\%), the genital organs (26-32\%), limbs (16-25\%), other reasons (16-25\%).

\section{IV.CONCLUSION}

Having analyzed the duration of productive using the cows of Holstein breed in the conditions of the breeding plant, it is possible to make yield conclusion that the main reasons for the retirement fat were diseases of the digestive system $(27-32 \%)$ and the genital organs (26-32\%).

Of the total number of retired cows, there were $25.4 \%$ of the animals retired after the 1 st lactation, $23.4 \%$ after the 2 nd one. The average lifetime milk production of retired cows for the first lactation is $7841.6 \mathrm{~kg}$, fat content $-4.3 \%$, mass share of protein is $3.2 \%$. The period of production use of the analyzed livestock amounts to 2.8 lactations. Cows from the $\mathrm{M}$. Chieftain's line are characterized by 3.0 lactations. At the same time, the retired cows of the line R. Sovering were characterized by higher productivity, the yield for lactation made $8462.8 \mathrm{~kg}$. The main reasons for cow retirement were the diseases of the limbs and the genital organs.

Therefore, the origin affects animal's growth, reproductive and milk quality, the duration of economic use. The cows of the line by R. Sovering were characterized by higher productive qualities during their first and third lactation. In the process of studying the effect of different methods of selection on milk productivity of Holstein breed cattle, the authors found that during intra-line selection higher productivity is characteristic of the selection by R. Sovering and V.B. Ideal. The period of production use of the analyzed livestock amounts to 2.8 lactations.

\section{References}

[1] S.S. Sinyakov, D.V. Novikov, V.G. Trufanov, "Comparative evaluation of the productive qualities of the Holstein breed of Dutch selection", Zootechnics, 2012, No. 12, p. 22.

[2] N.P. Sudarev, G.A. Sharkaeva, D. Abylkasymov et al, "Breeding cattle of Holstein and black-motley breeds at the farms of Russia in the Central Federal district and the Tver region", Zootechnics, 2015, No. 2, pp. 7-8.

[3] P.N. Prokhorenko, "Holstein breed and its influence on genetic progress in the productivity of black-motley cattle in European countries and the Russian Federation", Dairy and beef cattle, 2013, No. 2, pp. 2 - 6.

[4] V.S. Mymrin, S.V. Mymrin, O. Tkachuk, "The results of the genomic evaluation of servicing bulls bred in Russia", Zootechnics, 2014, No. 5, pp. 2-5.

[5] M.A. Chasovshchikova, "Improving the breeding and productive qualities of black-motley cattle of the Northern Urals", dissertation of Doctor of agricultural sciences: 06.02.07, Chasovshchikova Marina Alexandrovna. Tyumen, 2016, p. 380.

[6] O.M. Sheveleva, M.A. Svjazhenina, M.A. Chasovshchikova, "The exterior of the cattle of different origin", Siberian Herald of Agricultural Science, 2012, No. 5, pp. 42-46.

[7] M.A. Svjazhenina, T.P. Krinitcina, E.A. Ponomareva, "Holstein cattle in the North conditions", Bulletin of Orenburg State Agrarian University, 2017, №5 (67), pp. 163-166.

[8] N.A. Vasilyeva, A.V. Shumov, "Economic and biological peculiarities of cows of different production types of dairy breeds, bred in the northwest region of Russia", monograph, Vologda Dairy: IU VGMHL, 2013, p. 116.

[9] M.I. Selionova, G.P. Kovalyova, "Comparative evaluation of servicing bulls of the major dairy breeds in the productivity of daughters", Zootechnics, 2015, No. 1, pp. 8-10.

[10] E.V. Shapkanova, "Milk productivity of Holstein black-motley cattle", Herald Agroindustrial Complex of Upper Volga Region, 2011, No. 3, pp. 46-48.

[11] V.G. Kahikalo, O.V. Nazarchenko, "Breeding and productive qualities of daughters of servicing bulls of the Holstein line in the conditions of EV TRANS-Ural region”, Agrarnyj vestnik Urala, 2012, No. 4 (96), pp. 11 14.

[12] L. Ovchinikova, "The influence of cow's linear affiliation on their productive longevity", Dairy and beef cattle breeding, 2008, No. 1, pp. 7 8

[13] E. Voronina, N. Strekozov, F. Abrampalski, "The effect of selection of cows on their milk productivity", Dairy and beef cattle breeding, 2007 No. 4, pp. 8-9.

[14] M.A. Shishkina, "The influence of different forms of selection on the economic-useful traits of animals of Priobsky breed", Extended. Abst. Of the dissertation of Doctor of agricultural sciences, Novosibirsk, 2007, p. 21.

[15] I.A. Bakai, Bakai, A.V., Golubev A. A., "The effect of selection of parents on fertility of cows", Chief zootechnician, 2011, No. 11, p. 8.

[16] Ministry of Agriculture of the Russian Federation, "On approval of the order and conditions of carrying out the valuation of breeding cattle for dairy and dairy-beef production lines", order No. 379, from October 28th, 2010, retrieved from: http://www.garant.ru/products/ipo/prime/doc/2073537/\#ixzz4w20zo9So

[17] N.R. Zajnullina, "Characteristics of lines and their compatibility in a herd of cattle of black-motley breed", dissertation of Doctor of agricultural sciences, Moscow, 2000, p. 100.

[18] N. Zinoviev, N. Strekozov, E. Gladyr, "Connection of genetic heterogeneity with variability of dairy productivity of cows of different genealogical lines", Dairy and beef cattle breeding, 2013, No. 1, pp. 12 14.

[19] Chasovshchikova M.A., Sheveleva O.M., Svjazhenina M.A., Tatarkina N.I., Satkeeva A.B., Bakharev A.A., Ponomareva E.A, "Relationship between the genetic variants of kappa-casein and prolactin and the productive-biological characteristics of cows of the black-motley breed", Journal of Pharmaceutical Sciences and Research, Vol. 9(7), 2017, pp. 1038-1044, Retrieved from: http://www.jpsr.pharmainfo.in/Documents/Volumes/vo19Issue07/jpsr09 071704.pdf

[20] Kutrowski V., Ivanova N., Fetisova M., "Efficiency of selecting bulls for improvement of dairy cattle", Zootechnics, 2008, No. 2, p. 16.

[21] M. Boev, E.V. Kukushka, A.S. Noshchenko, "Assessment of intra-line crosses and breeding lines in dairy cattle based on inheritance of genetic markers", Bulletin of the Russian agricultural science, 2012, No. 4, pp. 72-75.

[22] M. A. Chasovshchikova, "Productive longevity of cows of black-motley and Holstein breeds", Collection of scientific works of all-Russian scientific research Institute of sheep breeding and goat breeding, 2014, Vol. 3, No. 7, pp. 302-305.

[23] S. G. Kulikova, N. N. Elkin, "Productive longevity of cows depending on Holstein breed pedigree and the linear affiliation", Herald of Novosibirsk State Agrarian University, 2010, No.3 (15), p. 69-72.

[24] M. A. Pilipenko, "Influence of servicing bulls on the duration of economic use of daughters", Agrarnyj vestnik Urala, 2011, No. 12-2, pp. 46-48. 
[25] N.E. Tatarkina, A.E. Belenkaya, "The duration of the productive use of Holstein cows in the conditions of Northern Transurals", Bulletin of State Agrarian University of Northern Transurals, 2017, No. 1, pp. 73-77. 